\title{
Researching Data Sets to Develop State Library Standards
}

\author{
Lesley S. J. Farmer, PhD \\ California State University Long Beach \\ lfarmer@csulb.edu
}

\begin{abstract}
California developed standards for library program factors that provide the conditions for students to meet library standard outcomes. To base those program standards empirically, the researchers analyzed three 2008-9 reputable data sets: California's school library data set, AASL's School Libraries Count data set, and a national School Library Journal data set. Standards were clustered into two sections: baseline factors, and statistical standards for resources. Findings revealed that school libraries that met the "baseline" standard were significantly different from those libraries that did not meet those standards. Once the baseline set of factors were determined, descriptive and correlational statistics were applied to the data sets, with the resultant figures based on the average figures supplied by those libraries that met the baseline factors.
\end{abstract}

\section{Introduction}

In 2009 the California Department of Education began developing library standards: student learning outcome standards and data-driven school library media program (SLMP) standards. Prior to this effort, library standards were embedded within other content standards, but the worth of the teacher librarian (TL) was lost in this process. The state's Education Code provided an option to develop stand-alone standards, which then could be used to validate the TL's unique role and contribution to student academic success. The SLMP standards were predicated on the assumption that certain resources needed to be in place for student library standards to be addressed effectively. The goal of my research was to develop baseline standards as well as service and quantitative resource standards for school library media program (SLMP) factors that provide the conditions for students to meet library outcomes, with a focus on California.

\section{Literature review}

Parsing the SLMP's elements, several variables were identified as contributing to student academic achievement: staffing (full-time teacher librarian and paraprofessional); the library facility itself as a physical learning environment (accessible all day with flexible scheduling); rich current library collections; instruction, collaboration, reading-related and other services (e.g., reference, loans, outreach); and program administration and planning. Compendiums of studies (e.g., Farmer, 2003; Library Service Research, Scholastic, 2008) and dozens of newer studies, including Achterman (2008) were examined.

\section{Research questions}

The goal of the project was to develop baseline standards as well as service and quantitative resource standards for school library media program (SLMP) factors that provide the conditions for students to meet library outcomes, with a focus on California. Several relevant research questions emerged.

- Which SLMP baseline variables significantly support student academic achievement?

- Do SLMPs that meet baseline variable standards differ significantly from SLMPs that do not meet those standards?

- What are the service and quantitative resource standards that are significantly correlated with those SLMPs that meet the baseline variable standards?

- Are California SLMPs significantly different from SLMPs nationally? 


\section{Methodology}

To further validate the variables, a 2008 national school library survey sponsored by the School Library Journal (SLJ) was consulted: the sample was representative of schools having professional librarians. To be established as a baseline standard for the current, at least half of the survey respondents had to meet that standard.

Once the baseline set of factors were determined, the California State Department of Education 2008 library data set was examined. A t-test was performed on the SLJ and California data sets to determine if a significant difference existed between the two, and none was found. Therefore, the two data sets could be used interdependently to develop the ultimate set of standards. A follow-up ANOVA statistical analysis determined the relative significance of the baseline variables, with variables being added one by one.

Next, the two data sets were divided into two sets: one that met all the baseline variable standards (CA1 and SLJ1), and the other set, which did not meet all the baseline variable standards (CA0 and SLJ0). A t-test was conducted to determine if a significant difference exists between set 1 and set 2 relative to resource and service standards.

The two data sets that met the baseline standards were then examined to determine the quantity of other SLMP variables. Descriptive statistics (including quartiles) and factor analysis were conducted on the quantitative values of the resources of the data sets CA1 and SLJ1 (those that met the baseline standards) in order to determine the relative strength of each variable.

\section{Findings}

Findings were used to generate service and quantitative resource standards.

The following tentative set of standards for school libraries emerged from the meta-analysis and survey data sets:

- One full-time teacher librarian

- One full-time paraprofessional

- Integrated library management system and OPAC

- Internet access for students

- Library open 36 hours or more per week

- At least some flexible scheduling

- Facilities: room and seating for one class and additional individuals, and the collection

- One class set of computers

- At least two online subscription databases

- Regular planning with at least one grade or department of teachers (20\% or more)

- Required services: readers' advisory/guidance, information literacy instruction, Internet and database instruction

- Current set of policies and procedures, and a yearly strategic plan that includes assessment

A significant difference at the .01 level existed between CA1 and CA0, and between SLJ1 and SLJ0. The number of SLMPs that met all the baseline standards (SLJ1) was 209:

- 37 (14.8\% of level's sample) elementary,

- 49 (29.2\% of level's sample) middle school,

- 114 senior high (44\% of level's population), and

- 9 other grade level combinations (8.7\% of level's sample).

The number of SLMPs that met all the baseline standards (CA1) was 352: 
- 13 elementary $(0.4 \%$ of level's sample),

- 69 middle school ( $8.2 \%$ of level's sample), and

- 267 senior high (44.9\% of level's sample), and

- 3 other grade level combinations (3.6\% of level's sample).

The main variable differentiating those SLMPs meeting the baseline standards and those not meeting the standard was the presence of a full-time teacher librarian.

A follow-up ANOVA analysis revealed more nuances differences. For the $S L J$ data set, the only single factors that were significantly different from those libraries that did not meet the baseline standards were book collection size, information literacy instruction, and instruction on Internet use. In contrast, for the California data set, not only were those factors significantly different, but the following additional factors were also significant: flexible scheduling (or mix of flexible and fixed), book and non-book budget, copyright date (i.e., currency of collection), having a library web site/portal, having at least two subscription databases, and planning with teachers.

\section{Discussion}

Taking the average figure for the variables in data sets CA1 and SLJ1, resource standards were generated. The variables and figures were also validated by several research studies and the 2008 AASL survey of SLMPs. These findings formed the basis of the state model "school library program standards." These standards follow.

Taking the average figure for the variables in data sets CA1 and SLJ1, the following resource standards were generated. When figures were significantly different relative to grade level, each set of figures was noted. When a discrepancy occurred between the two sets, both set of figures were noted. Figures were rounded to two significant figures for ease of reporting. The variables and figures were also validated by several research studies and the 2008 AASL survey of SLMPs.

- At least two-thirds of the print collection considered current (at least $50 \%$ of the collection more current than 1995 copyright date)

- Collection size base ( based on number of volumes): 13,000 for elementary; 15,000 for middle school; 20,000 for high school

- Book collection ratio to number of students: 20 books/elementary student, 18 books/middle school student, 12 books/high school student

- Collection development - adding books to the collection per year: 1 book/elementary student, 1 book/MS student, .5 book/HS student

- At least $\$ 5000$ spent on books (all grade levels) (California, 2008); note that on the national level that baseline amount would be $\$ 8000$

- At least $\$ 2000$ spent on non-books for elementary; $\$ 4000$ for middle school; $\$ 4000$ for high school (California, 2008); note that on the national level all grades would be $\$ 4000$; note that since California does not have a statewide subscription database agreement, the elementary figure could be raised to $\$ 4000$ taking into consideration county subscription databases

- At least $\$ 500$ spent on print periodicals (all grade levels)

- Total materials budget: standard of \$7,000 for elementary, \$9,000 for middle school and high school; alternatively $\$ 8000$ for all levels (the baseline median is $\$ 4000$ for elementary, $\$ 7500$ for middle school, $\$ 8000$ for high school, California, 2008); note that the national average figure is $\$ 8000$ for all levels, whether the SLMP met baseline standards or not

- Total material budget per student: $\$ 12 /$ elementary student, $\$ 8 /$ middle school student, $\$ 4 /$ high school student (California, 2008); note that the national average figures are \$14/elementary student, \$12/middle school student, $\$ 8 /$ high school student (baseline or not)

The two linked base standard variables most likely to be absent were staffing: having both a full-time teacher librarian and a librarian paraprofessional. In general, about three-quarters of California high school libraries have teacher librarians; national and state percentages of school libraries that met base standards was about the 
same: 44. That percentage of teacher librarians drops down to about half in middle schools and 17 percent in elementary settings. Therefore, it is no surprise that less than a half percent of California elementary school libraries met all the base standards, as opposed to almost fifteen percent of counterparts nationwide. That situation also differentiates California and national school libraries at the middle school level; less than 10 percent statewide versus almost thirty nationwide. Indeed, the teacher librarian per student ratio is the lowest in the nation, largely due to lack of professional staff at lower levels. Furthermore, teacher librarians are less likely to have a paraprofessional librarian on staff in California.

\section{Conclusion}

The California and national data sets confirmed the findings of dozens of studies correlating school library variables and student academic achievement. The one factor that (again) distinguishes high-quality SLMPs is staffing: a full-time teacher librarian and a full-time paraprofessional. The study also revealed that the baseline standards clearly differentiated achieving California SLMPs. Nevertheless, the national and state data sets were enough alike that California could be fairly compared with other states and held to national SLMP practices. California has a long way to go to insure that its school libraries provide the conditions needed to enable students can succeed academically. Nevertheless, the strength of the study was its basis on actual library practice, both at the state and national level. The methodology can be used in other settings to provide a databased look at best practices and identify important gaps in library program conditions.

\section{References}

Achterman, D. (2008). Haves, halves and have-nots: School libraries and student achievement. Doctoral dissertation. University of North Texas, Denton.

American Association of School Librarians. (2008). School libraries count! The second national survey of school library media programs. Chicago: American Library Association.

Farmer, L. (2003). Student success and library media programs. Westport, CT: Libraries Unlimited. Library Research Service. http://www.lrs.org/

School libraries count! (2008). New York: Scholastic.

Shontz, M., \& Farmer, L. (2009). School Library Journal's spending survey. School Library Journal (April), 3844. 